\title{
1 Impact of ionizing radiation on the environmental microbiomes of
}

\section{Chernobyl wetlands}

4 Elin Videvall ${ }^{1,2,3,4 *}$, Pablo Burraco ${ }^{4,5 *}$, and Germán Orizaola ${ }^{6,7}$

$6{ }^{1}$ Department of Ecology, Evolution and Organismal Biology, Brown University, Providence, RI 7 02912, USA

82 Institute at Brown for Environment and Society, Brown University, Providence, RI, 02912, 9 USA

$10{ }^{3}$ Center for Conservation Genomics, Smithsonian Conservation Biology Institute, 20013 11 Washington, DC, USA

$12{ }^{4}$ Animal Ecology, Department of Ecology and Genetics, Evolutionary Biology Centre, Uppsala 13 University, Norbyvägen 18D, SE-75236 Uppsala, Sweden

$14{ }^{5}$ Institute of Biodiversity, Animal Health and Comparative Medicine, College of Medical, 15 Veterinary and Life Sciences, University of Glasgow, Glasgow G12 8QQ, UK

${ }^{6}$ IMIB-Biodiversity Research Institute (Univ. Oviedo-CSIC-Princip. Asturias), Universidad de

Oviedo, Campus de Mieres, Edificio de Investigación 5a planta, c/ Gonzalo Gutiérrez Quirós s/n, 33600 Mieres-Asturias, Spain

$19{ }^{7}$ Zoology Unit, Department of Biology of Organisms and Systems, University of Oviedo, c/ 20 Catedrático Rodrigo Uría s/n, 33071 Oviedo-Asturias, Spain

* Elin Videvall and Pablo Burraco contributed equally to the study

Correspondence

Germán Orizaola, Zoology Unit, Department of Biology of Organisms and Systems, University of Oviedo, c/ Catedrático Rodrigo Uría s/n, 33071 Oviedo-Asturias, Spain.

27 Email: orizaolagerman@uniovi.es 


\section{Abstract}

Radioactive contamination in the form of ionizing radiation can be a devastating pollutant because it has the potential to cause damage to DNA and other biomolecules. Anthropogenic sources of ionizing radiation include accidents in nuclear power plants, such as the one in Chernobyl 1986, which caused long-term radioactive pollution. Studies on animals within radioactive zones have provided us with a greater understanding of how wildlife can persevere despite chronic radiation exposure, however, we still know very little about the effects of radiation on the microbial communities in the environment. Here, we examined the impact of ionizing radiation and other environmental factors on the diversity and composition of environmental microbiomes in the wetlands of Chernobyl. We combined extensive field sampling along a gradient of radiation together with 16S rRNA high-throughput metabarcoding (Illumina NovaSeq). While radiation did not affect the alpha diversity of the microbiomes in sediment, soil, or water, it had a strong effect on the beta diversity, indicating that the microbial composition was affected by ionizing radiation. Specifically, we detected several microbial taxa that were more abundant in areas with high radiation levels within the Chernobyl Exclusion Zone, including bacteria and archaea known to be radioresistant. Overall, our results reveal the existence of rich and diverse microbiomes in Chernobyl wetlands, with multiple taxonomic groups that are able to thrive despite the radioactive contamination. Further field and laboratory-based approaches will help to forecast the functionality and re-naturalization dynamics of radiocontaminated environments.

KEYWORDS bacteria, metabarcoding, microbiota, pollution, radioactivity 


\section{INTRODUCTION}

Human activities are transforming natural ecosystems at an unprecedented rate (Steffen et al., 2007). The intense use and transformation of natural habitats over the last decades have had a severe impact on biodiversity (Palumbi, 2001). Habitat destruction, climate alteration, invasive species, and the release of numerous pollutants into the environment are the main factors behind biodiversity decline (Rands et al., 2010). Pollutants, in particular, can affect species distribution and abundance, lead to the extirpation of the most susceptible ones, and alter biological functions, ecological networks and ecosystem services (Edwards, 2002).

lonizing radiation is a rare but potentially devastating pollutant. This type of radiation is present in the environment at low levels as a natural phenomenon (e.g. cosmic and terrestrial radiation), and generally does not cause damage to living organisms. However, certain human activities, such as weapons testing and accidents at nuclear power plants, can involve releases of ionizing radiation above safety levels. lonizing radiation may damage organic molecules, including DNA, and cause malfunctions in cell processes that lead to cellular and organismal death (Han \& Yu, 2010; Reisz et al., 2014). Indeed, the effects of exposure to acute levels of ionizing radiation are acknowledged to negatively impact organisms and ecosystems (Møller \& Mousseau, 2006, 2015).

The accident at the Chernobyl nuclear power plant, on the $26^{\text {th }}$ of April 1986, led to the largest release of radioactive material in human history (UNSCEAR, 1988). An exclusion zone of ca. $4,700 \mathrm{~km}^{2}$ was created around the power plant (Chernobyl Exclusion Zone, CEZ), preventing human settlement in the area, conditions that remains in effect. Exposure to the acute radiation levels generated by the Chernobyl accident caused a severe impact on the organisms in the area, including humans (Smith \& Beresford, 2005; Møller \& Mousseau, 2015). Studies on wildlife conducted after the accident reported that the radioactive contamination led to reductions in species diversity, multiple physiological costs, and increased DNA damage (Møller \& Mousseau, 2006, 2015). However, the effects of ionizing radiation are far from 
general; while some studies reported negative consequences on wildlife populations currently living in the area (e.g. Beaugelin-Seiller et al., 2020), others have reported population recoveries (e.g. Deryabina et al., 2015; Schlichting et al., 2019), and signs of adaptation to the chronic exposure (e.g. Galvan et al., 2014; Møller \& Mousseau, 2016). There is still an intense scientific debate about the long-lasting effects of chronic exposure to moderate levels of ionizing radiation on biodiversity (e.g. Møller \& Mousseau, 2006; Beresford et al., 2016, 2020). Bacterial communities are crucial for maintaining ecosystem functions due to their role in the cycling, retention, and release of major nutrients and soil carbon (Gucht et al., 2007; Newton et al., 2011; McKenney et al., 2018). Chronic exposure to pollutants, including ionizing radiation, can compromise the diversity and composition of bacterial communities (Chapin et al., 2000; Ager et al., 2010). A host-associated microbiome is predominantly constrained by the bacteria they are able to recruit from their environment, and the composition and diversity of the resulting microbial community in the host can have important effects on their health (Liu et al., 2019). Changes in the composition of environmental microbiomes as a consequence of chronic exposure to radiation can therefore have indirect effects on local wildlife by changing their capacity to acquire specific symbionts from the environment.

Despite the crucial ecological role of microbes in the environment, the impact of ionizing radiation on environmental microbiomes has not been comprehensively explored, and the Chernobyl accident represents an ideal opportunity in this regard (IAEA, 2006). Bacteria are often considered to have a greater resistance to ionizing radiation than other organisms (ICRP, 2014). Some bacterial taxa have been recovered from highly radio-contaminated environments, and, in some cases, their radioresistance capacity has been demonstrated under laboratory conditions (Ryabova et al., 2020). However, these studies have been restricted to a handful of taxa while the majority of environmental bacteria have never been studied in relation to radiation, neither in the laboratory nor in their natural environment. Shortly after the Chernobyl accident, studies on soil samples from the central area of the Chernobyl Exclusion Zone reported a two-fold lower abundance in bacteria, compared to control non- 
104 contaminated areas outside the Zone (Romanovskaya et al., 1998; Yablokov, 2009). Some

105 soil bacteria from the Chernobyl area were able to accumulate high doses of radioactive

106 substances (e.g. ${ }^{137} \mathrm{Cs}$ ), as in the case of Agrobacterium sp., Enterobacter sp., and Klebsiella

107 sp. (Yablokov, 2009). Chapon et al. analysed highly contaminated areas in the CEZ and

108 identified a high diversity of soil bacteria using a mix of culturing techniques and sequencing

109 tools (Chapon et al., 2012), whereas Hoyos-Hernandez et al. identified genes potentially

110 associated with radiation resistance in prokaryotes (Hoyos-Hernandez et al., 2019). Recent

111 studies have also examined the effects of radiation on the gut microbiome of wild vertebrates

112 (e. g. Ruiz-González et al., 2016, Lavrinienko et al., 2018a,b) and earthworms (Newbold et al.,

113 2019). Therefore, despite some progress, information on the bacterial communities present

114 along the gradient of radioactive contamination in Chernobyl is still scarce. Acquiring this

115 knowledge is not only relevant for evaluating the impact of radiation on microbes themselves,

116 but also for further comprehensive assessments of the impact of radiation on multicellular

117 organisms' host-associated microbiota.

118 In this study, we examined environmental factors affecting the diversity and

119 composition of bacterial communities in wetlands, by analyzing pond water, sediment, and soil

120 at multiple locations inside and outside the Chernobyl Exclusion Zone. We paid particular

121 attention to examining the impact of radioactive contamination on these environmental

122 microbiomes, but also evaluated other variables that might induce changes in bacterial

123 composition. Wetlands cover between $5-10 \%$ of the earth's land surface (Mitsch \& Gosselink,

124 2007) and provide essential ecosystem services such as carbon reservoirs (Mitsch et al.,

125 2013). As in other natural areas, Chernobyl wetlands are essential for a large number of

126 aquatic and terrestrial plants and animals. Understanding how ionizing radiation alters the

127 bacterial communities associated with these environments is crucial for a comprehensive evaluation of radio-contaminated ecosystems. 


\section{MATERIALS AND METHODS}

\subsection{Field work}

132 Sampling was conducted in Northern Ukraine, inside and outside the Chernobyl Exclusion

133 Zone between the $29^{\text {th }}$ of May and the 3rd of June 2019 (Figure 1, Table S1). In total, we

134 selected 21 permanent wetlands: 16 within the Chernobyl Exclusion Zone and 5 in a nearby

135 control area with background radiation levels (Figure 1, Table S1). All the sampled wetlands

136 shared similar characteristics: small to medium size wetlands with reed beds, situated within

137 a matrix of forest and meadows on sandy soils (soddy-podzolized sandy and clay-sandy soils;

138 Soil Map of Ukraine accessed from https://esdac.jrc.ec.europa.eu/content/title-russia-soil-

139 map-ukraine). To examine the diversity and composition of bacterial communities, at each site

140 we collected samples from three environment types: water, pond sediment, and soil near the

141 banks of the wetland. Each environment type was sampled at three points within each site. In

142 total, we collected 189 samples using tubed sterile Dryswab MW100 swabs with rayon tip. We

143 collected water samples by swirling a swab on the water surface for 25 seconds in areas about

144 one-meter depth, and about two meters from the shore. Sediment was collected at ca. $0.5 \mathrm{~m}$

145 depth with a sampler that removes the top $10 \mathrm{~cm}$ of sediment, and swabs were inserted into

146 the sediment five times for five seconds each time. Soil samples were collected on land, 5-10

147 meters from the water edge, by first removing the top $5 \mathrm{~cm}$ of soil and then twirling a swab

148 inside the exposed soil for 15 seconds. The swabs were placed in individual plastic vials on-

149 site and stored in a portable cooler until arrival at our laboratory in Chernobyl, where samples

150 were stored in a fridge at $4{ }^{\circ} \mathrm{C}$. Finally, we transported the samples to our laboratory at the

151 University of Oviedo (Spain), where they were stored at $-20^{\circ} \mathrm{C}$ until further processing.

152 At each site, we measured water chemical characteristics with a Hanna multiparametric

153 portable meter HI9811-5: temperature, $\mathrm{pH}$, total dissolved solids (TDS; ppm/mg/L), and

154 electrical conductivity $(\mathrm{EC} ; \mu \mathrm{S} / \mathrm{cm})$, at the same three sampling points where we collect the

155 water and sediment samples. We measured radiation levels (in $\mu$ Sv/h) with an MKS-AT6130 
156 handheld radiometer, at five points next to each environment type and site, by placing the

157 radiometer $5 \mathrm{~cm}$ above the sampled area (see Burraco et al., 2021 for details).

\subsection{DNA isolation, library preparation, and sequencing}

We used the DNeasy PowerSoil DNA isolation kit (Qiagen) to isolate DNA from soil and sediment samples, and the NZY Tissue gDNA isolation kit (NZYTech) to isolate DNA from water samples. We resuspended DNA in a final volume of 100 or $50 \mu \mathrm{L}$ when Qiagen or NZY kit were used, respectively. We included an extraction blank in every DNA extraction round and treated it as a regular sample to check for cross-contamination. reaction mixture was incubated as follows: an initial denaturation at $95{ }^{\circ} \mathrm{C}$ for $5 \mathrm{~min}$, followed ${ }^{\circ} \mathrm{C}$ for $7 \mathrm{~min}$.

For each sampled site, we pooled the three PCR replicates from each environment type (e.g. $3 \times$ water samples at each location). Once pooled, we attached the oligonucleotide

176 indices required for multiplexing in a second PCR with identical conditions as previously but 177 during 5 cycles and using $60^{\circ} \mathrm{C}$ as the annealing temperature (see Vierna et al., 2017). We

178 included a negative control in every PCR run to check for contamination during library 179 preparation. The libraries were run on $2 \%$ agarose gels stained with GreenSafe (NZYTech), 180 and imaged under UV light to verify the library size. Libraries were purified using the Mag-Bind

181 RXNPure Plus magnetic beads (Omega Biotek), and then pooled in equimolar amounts 
according to the quantification data provided by a Qubit dsDNA HS Assay (Thermo Fisher

183 Scientific). The pool was sequenced in a fraction of an Illumina NovaSeq paired end 250bp

184 run.

\subsection{Data processing}

187 We evaluated the quality of the reads using FastQC (Andrews, 2010) in combination with

188 MultiQC (Ewels et al., 2016). We next used DADA2 (Callahan et al., 2016) implemented in

189 QIIME2 (release 2020.2; Bolyen et al., 2018) to remove PCR primers, quality-filter reads,

190 denoise, merge the pairs, remove chimaeric reads, and cluster the resulting sequences into

191 amplicon sequence variants (ASVs). Forward and reverse reads were truncated at position

192249 before merging with a minimum overlapping region of 12 identical base pairs. Taxonomy

193 was assigned using a trained classifier of the SILVA reference database (Quast et al., 2013,

194 release 138 December 2019), with the feature-classifier classify-sklearn approach,

195 implemented in QIIME2 (Bokulich et al., 2018). A phylogenetic tree was constructed in QIIME2

196 (v. 2020.2), using MAFFT (Katoh \& Standley, 2013) and FastTree2 (Price et al., 2010) for

197 phylogenetic analyses.

198 The ASV table was imported into R (v. 4.0.2; R-Team-Core, 2020), and the packages

199 phyloseq (v. 1.32.0; McMurdie \& Holmes, 2013) and vegan (v. 2.5-6; Oksanen et al., 2019)

200 were used for statistical analysis. From downstream analyses, we excluded: the ASVs with a

201 single read in the whole dataset (singletons), the completely unassigned sequences (no

202 bacterial classification), and those from chloroplast and mitochondrial origin. We also removed

203 ASVs occurring at a frequency below $0.01 \%$ in each sample to account for potential

204 misassignments during library preparation and low-frequency contaminants. Furthermore, we

205 used decontam (v. 1.6.0; Davis et al., 2018) to identify and eliminate 9 potential contaminating

206 ASVs in the reagents by analyzing the blank samples that were sequenced simultaneously as

207 negative controls. A high and even read depth of high-quality sequences (average number of 
reads per sample $=41,210$ ) allowed us to safely rarefy the data to 30,000 reads without losing any samples or reducing statistical power.

\subsection{Statistical Analysis}

212 Sampling sites were assigned to three different areas regarding their location and radiation levels: CEZ-high for sites located inside the Chernobyl Exclusion Zone in environments with

214 soil and sediment radiation levels $>2 \mu \mathrm{Sv} / \mathrm{h}$; CEZ-low for sites located inside Chernobyl with 215 radiation levels $<0.5 \mu \mathrm{Sv} / \mathrm{h}$; and Outside-CEZ for sites outside Chernobyl, where radiation 216 levels were $<0.2 \mu \mathrm{Sv} / \mathrm{h}$ (Table S1). We calculated Alpha diversity for the bacterial communities 217 in water, pond sediment, and soil using three different metrics: Richness (i.e. total number of 218 unique ASVs), Shannon index (which takes into account both richness and evenness), and 219 Faith's index (i.e. phylogenetic diversity). Beta diversity was measured with the Bray-Curtis 220 distance metric, which accounts for both the presence/absence and abundance of microbes, 221 and with unweighted UniFrac, which measures phylogenetic distances between bacteria. We 222 used betadisper and adonis in the $\mathrm{R}$ package vegan to calculate homogeneity of group 223 dispersion and to perform PERMANOVAs to assess variation. Radiation levels $(\mu \mathrm{Sv} / \mathrm{h})$, Total 224 Dissolved Solids (TDS; ppm/mg/L), and Electrical Conductivity (EC; $\mu S / \mathrm{cm})$ were logtransformed prior to analysis. Finally, we used ANCOM with bias correction (ANCOM-BC, v. 0.99.1; Lin \& Peddada, 2020) on each environment type (water, sediment, soil), to identify

227 specific taxa that were associated with higher or lower radiation levels. In ANCOM-BC, we 228 used a conservative variance estimate and accounted for site location within or outside the 229 CEZ (group parameter).

\section{RESULTS}

232 We identified a total of 20,816 unique ASVs across the three environment types (surface water, 233 pond sediment, and soil) from the 21 sampled sites. Soil and pond sediment had the highest 
numbers of ASVs (soil $=11,553$, sediment $=11,033$ ), whereas the water samples had much fewer ASVs (water = 3,091; Fig. 2a). Despite the large diversity of microbes in both soil and pond sediment, the vast majority of ASVs was not shared across the sample types (Figure 2a). Water had substantially lower bacterial diversity (25\% lower) and richness ( $70 \%$ lower) than sediment and soil $(P<0.001$, in all cases). There were no differences in alpha diversity among the sites located within the CEZ (high and low radioactivity) and outside the CEZ, for any environment type (sediment, soil, water) (ANOVA of Shannon index: sediment, $F_{2,16}=0.29, P$ $=0.755$; soil, $F_{2,16}=1.51, P=0.252$; water, $F_{2,16}=0.55, P=0.588$; Fig. $2 \mathrm{~b}$ ). Similar results were obtained for ASV richness (sediment, $F_{2,16}=0.12, P=0.891$; soil, $F_{2,16}=1.24, P=0.315$; water, $F_{2,16}=0.37, P=0.698$; Fig. $2 \mathrm{c}$ ) and Faith's phylogenetic diversity (sediment, $F_{2,16}=0.18$, $P=0.834$; soil, $F_{2,16}=0.41, P=0.668$; water, $F_{2,16}=0.17, P=0.847 ;$ Fig. $2 \mathrm{~d}$ ). The effects of temperature and $\mathrm{pH}$ were not significant for any of these analyses $(P>0.159$, in all cases). We also found no correlation between radiation levels and bacterial diversity and richness in either of the three sample types $(P>0.32$, in all cases; Figure $\mathrm{S} 1)$.

The composition of environmental microbiomes differed substantially between the three environments $\left(R^{2}=17.5 \%, P<0.001\right)$, with the water microbiome being the most differentiated (Figure 3a). Analyses of sources of variance for each of the sample types using Bray-Curtis distances showed that radiation influenced the composition of both the sediment microbiome $\left(R^{2}=6.8 \%\right.$; Table 1 , Figure $\left.3 b\right)$ and the soil microbiome $\left(R^{2}=7.5 \%\right.$; Figure $\left.3 c\right)$.

253 Temperature significantly affected both the water microbiome $\left(R^{2}=8.2 \%\right)$ and the soil 254 microbiome $\left(R^{2}=7.7 \%\right.$; Table 1$)$, whereas dissolved solids had an effect on the water 255 microbiome composition $\left(R^{2}=10.3 \%\right.$; Table 1$)$. While radiation levels explained a decent 256 proportion of the water microbiome variance $\left(R^{2}=6.3 \%\right.$; Figure $\left.3 \mathrm{~d}\right)$, this effect was non257 significant $(P=0.066)$. In contrast, when analyzing microbiome composition with a 258 phylogenetic distance metric (UniFrac), radiation showed strong significant effects on both soil $259\left(R^{2}=7.2 \%, P=0.004\right)$ and water samples $\left(R^{2}=7.8 \% ; P=0.009\right)$, but not sediment microbiome $260\left(R^{2}=6.3 \%, P=0.08\right.$; Table S2). All group dispersion tests (function betadisper within vegan 
package) discarded any significant heterogeneity of environment microbiomes $(P>0.1)$,

262 indicating that the beta diversity differences in Table 1 and Figure 3 could not be explained

263 simply by sample dispersion.

The taxonomic analysis of environment microbiomes showed that sediment and soil communities had a diverse composition consisting of multiple abundant phyla, with Actinobacteriota more abundant in soil and Desulfobacterota more common in sediment

(Figure 4). Water communities consisted almost exclusively of Proteobacteria and

Bacteroidota (Figure 4). The effects of radiation on specific members of the microbiomes evaluated using ANCOM-BC revealed several bacterial families with higher abundances in the localities with higher radioactivity (Figure 5). The majority of the taxa that were positively associated with radiation levels were unique to their respective environment microbiome; for example, Prolixibacteraceae in soil, Methylococcaceae in sediment, and Rhodocyclaceae in water. However, some taxa were differentially abundant across sample types, e.g.

274 Lentimicrobiaceae was more abundant at the high-radiation localities in both soil and water 275 microbiomes, and Eubacterium coprostanoligenes group was more abundant at the high276 radiation localities in both sediment and water. Families associated with higher abundance in 277 high-radiation areas also included Anaerolineae and Thermoplasmata in sediment or 278 Smithellaceae and Geobacteraceae in water; whereas families with lower abundances in highradiation soil microbiomes included Micromonosporaceae, Microbacteriaceae, TK10,

280 Fibrobacteraceae, and Chthoniobacteraceae (Figure 5).

\section{DISCUSSION}

283 Chernobyl wetlands maintain rich and diverse microbial communities three decades after the

284 accident in the nuclear power plant. Our study reveals that the diversity and richness of 285 bacterial communities in pond sediment, shore soil, and water were similar between wetlands 286 sampled inside and outside the Chernobyl Exclusion Zone, and that these two parameters 
were not influenced by radiation levels. However, the beta diversity and composition of the

bacterial communities in Chernobyl wetlands were affected by different environmental factors, with radioactivity being the main effect. In addition, we discovered several bacterial families with higher abundance in sites with high radiation levels. Understanding how bacterial communities are influenced by radioactive contamination is crucial for evaluating the impact of the Chernobyl accident in the environment and to forecast the future development of the ecosystems in the area.

Our study presents the most comprehensive assessment of bacterial communities in areas affected by the Chernobyl accident to date, reporting more than 20,000 unique ASVs. It effectively builds upon previous studies of the area, which used other techniques rather than metabarcoding to identify bacteria (Theodorakopoulos et al., 2017; Lavrinenko et al., 2018a,b; Chapon et al., 2012). By using metabarcoding, we found substantial differences between environments, with very high bacterial richness and diversity across all soil and sediment microbiomes. These results corroborate the findings in the Earth Microbiome Project (EMP), where sediment and soil microbiomes were shown to vastly outnumber all other free-living microbial communities in terms of bacterial richness (Thompson et al., 2017). Similar to the EMP, our water microbiomes had much lower richness and differed in community composition.

304 Stark microbial differences across environment types are not surprising given their highly differentiated characteristics (e.g. microclimate and environmental components).

307 of radioactive contamination, or between samples collected inside Chernobyl and in areas with 308 background radiation levels outside the Exclusion Zone. This finding agrees with previous 309 studies that sampled biofilm communities and bacteria in trenches for radioactive waste 310 disposal in Chernobyl, both reporting that the diversity of bacteria did not change between 311 sites with high and low levels of radiation, or even when compared with remote, non312 contaminated areas, although these studies were only able to examine a low number of OTUs 313 (Ragon et al., 2011; Chapon et al., 2012). A small localized study found more bacterial OTUs 
314 in the high-radiation samples than in the low-radiation samples (Theodorakopoulos et al., 315 2017). Other studies, however, have reported a lower diversity of bacteria from the most highly 316 radio-contaminated sites. For example, the diversity of cultured bacteria sampled in the 10-km

317 zone around the Chernobyl Nuclear Power Plant was two orders of magnitude lower than in 318 control, non-contaminated areas (Romanovskaia et al., 1998). Similarly, the diversity of soil bacterial communities was lower in samples from the most highly radio-contaminated areas within Fukushima (Ihara et al., 2021). There are some possible factors behind this large 321 variation in microbial diversity results across studies. The combination of using a 322 metabarcoding technique with high-throughput sequence data (Illumina NovaSeq) and 323 extensive environmental sampling allowed us to conduct a comprehensive evaluation of the 324 bacterial communities in the area. This methodological implementation led to a massive improvement in the detection of bacteria compared to previous studies, including lineages that 326 are rare or hard to culture (Woo et al., 2008; Joos et al., 2020). In addition, the bacterial 327 communities in the area are likely to differ between wetlands and terrestrial environments 328 which have been targeted in previous studies (e.g. Romanovskaia et al., 1998; Chapon et al., 329 2012; Theodorakopoulos et al., 2017). Furthermore, over thirty years have passed since the 330 accident in Chernobyl, and the chronic exposure to low-dose radiation may have facilitated the 331 proliferation of bacteria resistant to radiation (already suggested by Zavilgelsky et al., 1998), which may explain why some of the studies conducted closer in time to the nuclear accidents 333 in Chernobyl (Romanovskaia et al., 1998) or Fukushima (Ihara et al., 2021) found lower 334 bacterial diversity measures. Bacterial adaptation to radioresistance can result from relatively 335 small genetic changes affecting DNA repair and metabolic functions (DeVeaux et al., 2007; 336 Harris et al., 2009; Byrne et al., 2014), and these evolutionary responses are much more likely 337 to appear with increasing time after radiation exposure.

338 The composition of bacterial communities in Chernobyl wetlands was affected by 339 diverse environmental factors, including radiation. Overall, soil communities were 340 characterized by the abundance of Actinobacteriota, a phylum typically dominant in this 
environment (Hill et al., 2011), abundant also in previous studies in Chernobyl

342 (Theodorakopoulos et al., 2017). Water communities were dominated by Proteobacteria and

343 Bacteroidota, two of the most common phyla of bacteria in freshwater environments (Newton

344 et al., 2011). When examined using Bray-Curtis dissimilarity, the composition of bacterial communities in water was affected by the amount of dissolved organic matter and water temperature, both of which have been previously recognized as potential drivers of bacterial community structure (e.g. Judd et al., 2006; Hall et al., 2008). Soil and sediment community structure was mostly influenced by radiation levels. Although $\mathrm{pH}$ has been shown to be a key determinant of the composition of bacteria communities in Chernobyl (Antwis et al., 2021), and elsewhere (e.g. Griffiths et al., 2011; Zhalnina et al., 2015), we did not detect any significant effect of $\mathrm{pH}$ in any of the sampled environments. When using UniFrac phylogenetic distances, the effect of radiation was strongly significant in soil and water, indicating that radiation has a strong effect on the phylogenetic composition of the microbiome in these environments. detected when examining the taxonomic composition of the different microbiomes. In particular, we identified several bacterial families with higher abundances in sites with higher radioactivity. Among them, many taxa are reported as common in radioactive environments, with some being able to reduce uranium and other radioactive metals. For example, several of the taxa that were more abundant in water with high radiation levels included Rhodocyclaceae,

360 Smithellaceae, Geobacteraceae, Synthrophales and Desulfobaccaceae. Rhodocyclaceae is a

361 family that includes UV-radiation resistant members (Han et al., 2020) and has been detected 362 also in the Handford 300 area, a former complex for radioactive fuel manufacture (Converse 363 et al., 2015). Geobacteraceae are metal-reducers that have been frequently found in areas 364 rich in uranium (Suzuki et al., 2005; Simonoff et al., 2007; N'Guessan et al., 2010; Zachara et 365 al., 2013, Sutcliffe et al., 2018). Smithellaceae, Desulfobaccaceae and Synthrophales have 366 also been detected in disposal sites for liquid radioactive waste and experimental areas with 367 radionuclide contamination (Nazina et al., 2010, Vikmna et al., 2019, Gihring et al., 2021). In 
our study, among the microbes that were more abundant in high radiation sediment samples were Anaerolineae, Microbacterium and the archaea Thermoplasmata. These three taxa have also been previously associated with uranium-rich soils (Mondani et al., 2011), groundwater

371 from nuclear waste depositories (Nedelkova et al., 2007), and radioactive legacy sites 372 (Vazquez-Campos et al., 2021), respectively. Prolixibacteraceae, which were associated with high soil radiation levels in our study, have also been detected in bogs with high levels of 374 radioactive selenium, cesium, thorium and uranium (Lusa \& Bomberg, 2021). Several of the 375 groups that were abundant in high radiation soils, e.g. Lentimicrobiaceae, are slow-growing 376 bacteria associated with polluted environments. Radioresistant bacteria often have slow 377 growth cycles, diverting their resources from growth to DNA repair and stress resistance 378 mechanisms (Zakrzewska et al., 2011). For some of the other taxa, we still have little 379 information about their ecological requirements, in particular any potential resistance to radiation. Further studies on the effects of radioactivity on specific microbial taxa are therefore 381 necessary.

In summary, we detected rich and diverse microbial communities in the wetlands of the

383 Chernobyl Exclusion Zone, regardless of radiation levels. Multiple bacterial and archaeal taxa 384 had higher abundance in the high-radiation sites, many of which were previously reported to 385 thrive in other areas with high radioactivity. By using extensive field sampling together with 386 metabarcoding and high-throughput sequencing, our study significantly contributes to our 387 understanding of the drivers that affect the diversity and composition of bacterial communities 388 in radio-contaminated environments. The host-associated microbiomes of multicellular 389 organisms (plants and animals) that live in these highly radioactive areas may be directly 390 sourced from the microbial communities present in the local environment (as suggested by 391 Jones et al., 2004). Thus, an improved knowledge of how environmental microbiomes respond 392 to a gradient of radioactivity is therefore crucial to forecast the future functionality and re393 naturalization potential of radiocontaminated environments. 


\section{ACKNOWLEDGEMENTS}

We are thankful to Sergey Gaschack for his invaluable help with field sampling and radiation evaluation, and to the staff of the Chornobyl Center for Nuclear Safety, Radioactive Waste and Radioecology (Slavutych, Ukraine) for their support during field research. We thank AllGenetics \& Biology SL for help with DNA metabarcoding work and great analytical support. Katerina Guschanski provided valuable comments on initial stages of the study. This work was supported by projects from the Helge Ax:son Johnsons Stiftelse to PB, and Swedish Radiation Protection Agency-SSM (SSM2018-2038) and Carl Tryggers Foundation (CT 16:344) to GO. EV was supported by a fellowship from the Swedish Research Council (2020-00259), PB by a Carl Tryggers Foundation scholarship (CT 16:344) and by a Marie Sklodowska-Curie fellowship (METAGE-797879), and GO by the Spanish Ministry of Science, Innovation and Universities "Ramón y Cajal” grant RYC-2016-20656.

\section{AUTHOR CONTRIBUTIONS}

G.O. conceived the study. P.B. and G.O. conducted field surveys and sample collection. E.V. analyzed the data. E.V. and G.O. wrote the manuscript with significant contributions from P.B.

\section{CONFLICT OF INTEREST}

The authors declare no conflict of interest.

\section{DATA AVAILABILITY STATEMENT}

Detailed information of all sampling sites is available in the supplementary information. The sequence reads have been uploaded to EMBL-EBI ENA and will be made public upon acceptance of the manuscript.

419

420

421

422

423

424

425

426

427

428

429

430

431

432

433

434

435

436

437

438

439

440

441

442

443

444

445

446

\section{REFERENCES}

Ager, D., Evans, S., Li, H., Lilley, A. K., \& Van Der Gast, C. J. (2010). Anthropogenic disturbance affects the structure of bacterial communities. Environmental Microbiology, $12,670-678$

Andrews, S. (2010). FastQC: A quality control tool for high throughput sequence data. http://www.bioinformatics.babraham.ac.uk/projects/fastacl

Antwis, R. E., Beresford, N. A., Jackson, J.A., et al. (2021). Impacts of radiation exposure on the bacterial and fungal microbiome of small mammals in the Chernobyl Exclusion Zone. Journal of Animal Ecology, 90, 2172-2187.

Apprill, A., McNally, S., Parsons, R., \& Weber, L. (2015). Minor revision to V4 region SSU rRNA 806R gene primer greatly increases detection of SAR11 bacterioplankton. Aquatic Microbial Ecology, 75, 129-137.

Beaugelin-Seiller, K., Garnier-Laplace, J., Della-Vedova, C., Métivier, J.-M., Lepage, H., Mousseau, T. A. \& Møller, A. P. (2020). Dose reconstruction supports the interpretation of decreased abundance of mammals in the Chernobyl Exclusion Zone. Scientific Reports, $10,14083$.

Beresford, N. A., Fesenko, S., Konoplev, A., Skuterud, L., Smith, J. T., \& Voigt. G. (2016). Thirty years after the Chernobyl accident: what lessons have we learnt? Journal of Environmental Radioactivity, 157, 77-89.

Beresford, N. A. et al. (2020). Towards solving a scientific controversy - The effects of ionising radiation on the environment. Journal of Environmental Radioactivity, 211, 106033.

Bokulich, N. A., Kaehler, B. D., Rideout, J. R., Dillon, M., Bolyen, E., Knight, R., Huttley, G. A., Caporaso, J. G. (2018). Optimizing taxonomic classification of marker-gene amplicon sequences with QIIME 2's q2-feature-classifier plugin. Microbiome, 6, 90.

Bolyen, E., Rideout, J.R., Dillon, M.R., Bokulich, N.A., Abnet, C., Al-Ghalith, G.A., Alexander, H., Alm, E.J., Arumugam, M., Asnicar, F., et al. (2019). QIIME 2: Reproducible, interactive, 
scalable, and extensible microbiome data science using QIIME 2. Nature Biotechnology, 37, 852-857.

Burraco, P., Car, C., Bonzom, J.-M., \& Orizaola, G. (2021). Assessment of exposure to ionizing radiation in Chernobyl tree frogs (Hyla orientalis). Scientific Reports, 11, 20509.

Byrne, R. T., Chen, S.H., Wood, E. A., Cabot, E. L. \& Cox, M. M. (2014). Escherichia coli genes and pathways involved in surviving extreme exposure to ionizing radiation. Journal of Bacteriology, 196, 3534-3545.

Callahan, B. J., McMurdie, P. J., Rosen, M. J., Han, A. W., Johnson, A. J. A., \& Holmes, S. P. (2016). DADA2: High-resolution sample inference from Illumina amplicon data. Nature Methods, 13, 581.

Chapin, F. S. III et al. (2000). Consequences of changing biodiversity. Nature, 405, 234-242.

Chapon, V. et al. (2012). Microbial diversity in contaminated soils along the T22 trench of the Chernobyl experimental platform. Applied Geochemistry, 27, 1375-1383.

Converse, B. J., McKinley, J. P., Resch, C. T., \& Roden, E. E. (2015). Microbial mineral colonization across a subsurface redox transition zone. Frontiers in Microbiology, 6, 858.

Davis, N. M., Proctor, D. M., Holmes, S. P., Relman, D. A., \& Callahan, B. J. (2018). Simple statistical identification and removal of contaminant sequences in marker-gene and metagenomics data. Microbiome, 6, 226.

Deryabina, T. G., Kuchmel, S. V., Nagorskaya, L. L., Hinton, T. G., Beasley, J. C., Lerebours, A., \& Smith, J. T. (2015). Long-term census data reveal abundant wildlife populations at Chernobyl. Current Biology, 25, R824-R826.

DeVeaux, L. C., Müller, J. A., Smith, J., Petrisko, J., Wells, D. P., \& DasSarma, S. (2007). Extremely radiation-resistant mutants of a halophilic archaeon with increased singlestranded DNA-binding protein (RPA) gene expression. Radiation Research, 168, 507-514.

Edwards, C. A. (2002). Assessing the effects of environmental pollutants on soil organisms, communities, processes and ecosystems. European Journal of Soil Biology, 38, 225-231.

Ewels, P., Magnusson, M., Lundin, S., \& Käller, M. (2016). MultiQC: Summarize analysis results for multiple tools and samples in a single report. Bioinformatics, 32, 3047-3048.

Galván, I., Bonisoli-Alquati, A., Jenkinson, S., Ghanem, G., Wakamatsu, K., Mousseau, T. A. \& Møller, A. P. (2014). Chronic exposure to low-dose radiation at Chernobyl favours adaptation to oxidative stress in birds. Functional Ecology, 28, 1387-1403.

Gihring, T. M., Zhang, G., Brandt, C. C., Brooks, S. C., Campbell, J. H., Carroll, S., Criddle, C. S., Green, S. J., Jardine, P., Kostka, J. E., Lowe, K., Mehlhorn, T. L., Overholt, W., Watson, D. B., Yang, Z., Wu, W. M., \& Schadt, C. W. (2011). A limited microbial consortium is responsible for extended bioreduction of uranium in a contaminated aquifer. Applied and Environmental Microbiology, 77, 5955-5965.

Griffiths, R. I., Thomson, B. C., James, P., Bell, T., Bailey, M., \& Whiteley, A. S. (2011). The bacterial biogeography of British soils. Environmental Microbiology, 13, 1642-1654.

Gucht, K. V. D. et al. (2007). The power of species sorting: local factors drive bacterial community composition over a wide range of spatial scales. Proceedings of the National Academy of Sciences USA, 104, 20404-20409.

Hall, E., Neuhauser, C., \& Cotner, J. (2008). Toward a mechanistic understanding of how natural bacterial communities respond to changes in temperature in aquatic ecosystems. ISME Journal, 2, 471-481.

Han, J. H., Maeng, S., Park, Y., Lee, S. E., Lee, B.-H., Lee, K., \& Kim, M. K. (2020). Identification of 12 radiation-resistant bacterial species in the phylum Proteobacteria new to Korea. Journal of Species Research, 9, 85-104.

Han, W., \& Yu, K. N. (2010). lonizing radiation, DNA double strand break and mutation. Advances in Genetics research, 4, 197-210.

Harris, D. R., Pollock, S. V., Wood, E. A., Goiffon, R. J., Klingele, A. J., Cabot, E. L., Schackwitz, W., Martin, J., Eggington, J., Durfee, T. J., Middle, C. M., Norton, J. E., Popelars, M. C., Li, H., Klugman, S. A., Hamilton, L. L., Bane, L. B., Pennacchio, L. A., 

radiation resistance in Escherichia coli. Journal of Bacteriology, 191, 5240-5252.

Hill, P., Krištùfek, V., Dijkhuizen, L., Boddy, C., Kroetsch, D., \& van Elsas, J. D. (2011). Land use intensity controls actinobacterial community structure. Microbial Ecology, 61, 286302.

Hoyos-Hernandez, C., Courbert, C., Simonucci, C., David, S., Vogel, T. M., \& Larose, C. (2019). Community structure and functional genes in radionuclide contaminated soils in Chernobyl and Fukushima. FEMS Microbiology Letters, 366, fnz180.

IAEA (2006). Environmental consequences of the Chernobyl accident and their remediation: twenty years of experience. Report of the Chernobyl Forum Expert Group 'Environment'. IAEA Radiological assessment reports series. Vienna.

ICRP (2014). Protection of the environment under different exposure situations. International Commission on Radiological Protection Publication 124. Annals ICRP 43.

Ihara, H., Kumagai, A., Hori, T., Nanba, K., Aoyagi, T., Takasaki, M., \& Katayaman, Y. (2021). Direct comparison of bacterial communities in soils contaminated with different levels of radioactive cesium from the first Fukushima nuclear power plant accident. Science of the Total Environment, 756, 143844.

Jones, H. E., West, H. M., Chamberlain, P. M., Parekh, N. R., Beresford, N. A., \& Crout, N. M. J. (2004). Effects of gamma irradiation on Holcus lanatus (Yorkshire fog grass) and associated soil microorganisms. Journal of Environmental Radioactivity, 74, 57-71.

Joos, L., Beirinckx, S., Haegeman, A., Debode, J., Vandecasteele, B., Baeyen, S., Goormachtig, S., Clement, L., \& De Tender, C. (2020). Daring to be differential: metabarcoding analysis of soil and plant-related microbial communities using amplicon sequence variants and operational taxonomical units. BMC Genomics, 21, 1-17.

Judd, K. E., Crump, B. C., \& Kling, G. W. (2006). Variation in dissolved organic matter controls bacterial production and community composition. Ecology, 87, 2068-2079.

Katoh, K, \& Standley, D. M. (2013). MAFFT multiple sequence alignment software version 7: improvements in performance and usability. Molecular Biology and Evolution, 30, 772780.

Lavrinienko, A., Mappes, T., Tukalenko, E., Mousseau, T. A., Møller, A. P., Knight, R., Morton, J. T., Thompson, L. R., \& Watts, P. C. (2018a). Environmental radiation alters the gut microbiome of the bank vole Myodes glareolus. ISME Journal, 12, 2801-2806.

Lavrinienko, A., Tukalenko, E., Mappes, T., \& Watts, P. C. (2018b). Skin and gut microbiomes of a wild mammal respond to different environmental cues. Microbiome, 6, 209.

Lin, H., \& Peddada, S. D. (2020). Analysis of compositions of microbiomes with bias correction. Nature Communications, 11, 3514.

Liu, H., Macdonald, C. A., Cook, J., Anderson, I. C., \& Singh, B. K. (2019). An ecological loop: host microbiomes across multitrophic interactions. Trends in Ecology and Evolution, 34, 1118-1130.

Lusa, M., \& Bomberg, M. (2021). Microbial community composition correlates with metal sorption in an ombrotrophic boreal bog: implications for radionuclide retention. Soil Systems, 5, 19.

McKenney, E. A., Koelle, K., Dunn, R. R., \& Yoder, A. D. (2018). The ecosystem services of animal microbiomes. Molecular Ecology, 27, 2164-2172.

McMurdie, P. J., \& Holmes, S. (2013). phyloseq: An R package for reproducible interactive analysis and graphics of microbiome census data. PLOS ONE, 8, e61217.

Mitsch, W. J., \& Gosselink, J. G. (2007). Wetlands, 4th ed. John Wiley \& Sons, Hoboken, NJ. Mitsch, W. J., Bernal, B., Nahlik, A. M., Mander, U. I., Zhang, L., Anderson, C. J., Jørgensen, S. E., \& Brix, H. (2013). Wetlands, carbon, and climate change. Landscape Ecology, 28, 583-597.

Møller, A. P., \& Mousseau, T. A. (2006). Biological consequences of Chernobyl: 20 years on. Trends in Ecology and Evolution, 21, 200-207. 
Møller, A. P., \& Mousseau, T. A. (2015). Strong effects of ionizing radiation from Chernobyl on mutation rates. Scientific Reports, 5, 8363.

Møller, A. P., \& Mousseau, T. A. (2016). Are organisms adapting to ionizing radiation at Chernobyl? Trends in Ecology and Evolution, 31, 281-289.

Mondani, L. et al. (2011). Influence of uranium on bacterial communities: a comparison of natural uranium-rich soils with controls. PLoS One, 6, e25771.

N'Guessan, A. L., Elifantz, H., Nevin, K. P., Mouser, P. J., Methé, B., Woodard, T. L., Manley, K., Williams, K. H., Wilkins, M. J., Larsen, J. T., Long, P. E., \& Lovley, D. R. (2010). Molecular analysis of phosphate limitation in Geobacteraceae during the bioremediation of a uranium-contaminated aquifer. ISME Journal, 4, 253-266.

Nazina, T. N. et al. (2010). Microorganisms in a disposal site for liquid radioactive wastes and their influence on radionuclides. Geomicrobiology Journal, 27, 473-486.

Nedelkova, M., Merroun, M. L., Rossberg, A., Hennig, C., \& Selenska-Pobell, S. (2007). Microbacterium isolates from the vicinity of a radioactive waste depository and their interactions with uranium. FEMS Microbiology Ecology, 59, 694-705.

Newbold, L. K., Robinson, A., Rasnaca, I., Lahive, E., Soon, G. H., Lapied, E., Oughton, D., Gashchak, G., Beresford, N. A., \& Spurgeon, D. J. (2019). Genetic, epigenetic and microbiome characterisation of an earthworm species (Octolasion lacteum) along a radiation exposure gradient at Chernobyl. Environmental Pollution, 255, 113238.

Newton, R. J., Jones, S. E., Eiler, A., Mcmahon, K. D., \& Bertilsson, S. (2011). A guide to the natural history of freshwater lake bacteria. Microbiology and Molecular Biology Reviews, 75, 14-49.

Oksanen, J. et al. (2019). vegan: Community Ecology Package. - R Package. version 2.5-6.

Palumbi, S. R. (2001). Humans as the world's greatest evolutionary force. Science, 293, 17861790.

Parada, A. E., Needham, D. M., \& Fuhrman, J. A. (2016). Every base matters: Assessing small subunit rRNA primers for marine microbiomes with mock communities, time series and global field samples. Environmental Microbiology, 18, 1403-1414.

Price, M. N., Dehal, P. S., \& Arkin, A. P. (2010). FastTree 2 - Approximately maximumlikelihood trees for large alignments. PLoS ONE, 5, e9490.

Quast, C., Pruesse, E., Yilmaz, P., Gerken, J., Schweer, T., Yarza, P., Peplies, J., \& Glöckner, F. O. (2013). The SILVA ribosomal RNA gene database project: improved data processing and web-based tools. Nucleic Acids Research, 41, D590-596.

Rands, M. R. W. et al. (2010). Biodiversity conservation: challenges beyond 2010. Science, 329,1298-1303.

Ragon, M., Restoux, G., Moreira, D., Møller, A. P., \& López-García, P. (2011). Sunlightexposed biofilm microbial communities are naturally resistant to Chernobyl ionizingradiation levels. PLoS ONE, 6, e21764.

Reisz, J. A., Bansal, N., Qian, J., Zhao, W., \& Furdui, C. M. (2014). Effects of ionizing radiation on biological molecules-mechanisms of damage and emerging methods of detection. Antioxidants \& Redox Signaling, 21, 260-292.

Romanovskaya, V. A., Sokolov, I. G., Rokitko, P. V., \& Chernaya, N. A. (1998). Ecological consequences of radioactive contamination for soil bacteria in the 10-km Chernobyl zone. Microbiology, 67, 274-280.

Ruiz-González, M., Czirják, G., Genevaux, P., Møller, A. P., Mousseau, T. A., \& Heeb, P. (2016). Resistance of feather-associated bacteria to intermediate levels of ionizing radiation near Chernobyl. Scientific Reports, 6, 22969.

Ryabova, A., Kozlova, O., Kadirov, A., Ananeva, A., Gusev, O., \& Shagimardanova, E. (2020). DetR DB: A database of ionizing radiation resistance determinants. Genes, 11, 1477.

Schlichting, P. E., Love, C. N., Webster, S. C., \& Beasley, J. C. (2019). Efficiency and composition of vertebrate scavengers at the land-water interface in the Chernobyl Exclusion Zone. Food Webs, 18, e00107. 
603

604

605

606

607

608

609

610

611

612

613

614

615

616

617

618

619

620

621

622

623

624

625

626

627

628

629

630

631

632

633

634

635

636

637

638

639

640

641

642

643

644

Simonoff, M., Sergeant, C., Poulain, S., \& Pravikoff, M. S. (2007). Microorganisms and migration of radionuclides in environment. Comptes Rendus Chimie, 10, 1092-1107.

Smith, J. T. \& Beresford, N. A. (2005). Chernobyl - Catastrophe and consequences. Springer, Berlin.

Steffen, W., Crutzen, P. J., \& McNeill, J. R. (2007). The Anthropocene: are humans now overwhelming the great forces of nature. $A M B I O, 36,614-621$.

Sutcliffe, B. et al. (2018). Insights from the genomes of microbes thriving in uranium-enriched sediments. Microbial Ecology, 75, 970-984.

Suzuki, Y., Kelly, S. D., Kemner, K. M., \& Banfield, J. F. (2005). Direct microbial reduction and subsequent preservation of uranium in natural near-surface sediment. Applied Environmental Microbiology, 71, 1790-1797.

Theodorakopoulos, N. et al. (2017). Soil prokaryotic communities in Chernobyl waste disposal trench T22 are modulated by organic matter and radionuclide contamination. FEMS Microbiology Ecology, 93, fix079.

Thompson, L., Sanders, J., McDonald, D. et al. (2017). A communal catalogue reveals Earth's multiscale microbial diversity. Nature, 551, 457-463.

UNSCEAR (1988). Sources, effects and risks of ionizing radiation. United Nations Scientific Committee on the Effects of Atomic Radiation 1988 Report to the General Assembly, with annexes. United Nations. New York, USA.

Vierna, J., Doña, J., Vizcaino, A., Serrano, D., \& Roger, J. (2017). PCR cycles above routine numbers do not compromise high-throughput DNA barcoding results. Genome, 60, 868873.

Vikman, M. et al. (2019). The biogeochemistry of gas generation from low-level nuclear waste: Microbiological characterization during 18 years study under in situ conditions. Applied Geochemistry, 105, 55-67.

Woo, P. C., Lau, S. K., Teng, J. L., Tse, H., Yuen, K. Y. (2008). Then and now: use of $16 \mathrm{~S}$ rDNA gene sequencing for bacterial identification and discovery of novel bacteria in clinical microbiology laboratories. Clinical Microbiology and Infection, 14, 908-934.

Yablokov, A. V. (2009). Chernobyl's radioactive impact on microbial biota. Annals of the New York Academy of Sciences, 1181, 281-284.

Zachara, J. M. et al. (2013). Persistence of uranium groundwater plumes: contrasting mechanisms at two DOE sites in the groundwater-river interaction zone. Journal of Contaminant Hydrology, 147, 45-72.

Zakrzewska, A. et al. (2011). Genome-wide analysis of yeast stress survival and tolerance acquisition to analyze the central trade-off between growth rate and cellular robustness. Molecular Biology of the Cell, 22, 4435-4446.

Zavilgelsky, G. B., Abilev, S. K., Sukhodolets, V. V., \& Ahmad, S. I. (1998). Isolation and analysis of UV and radio-resistant bacteria from Chernobyl. Journal of Photochemistry and Photobiology B: Biology, 43, 152-157.

Zhalnina, K., Dias, R., de Quadros, P. D., Davis-Richardson, A., Camargo, F. A. O., Clark, I. M., McGrath, S. P., Hirsch, P. R., \& Triplett, E. W. (2015). Soil pH determines microbial diversity and composition in the park grass experiment. Microbial Ecology, 69, 395-406. 
645 FIGURE 1 Map showing the sampling sites in Northern Ukraine. Abbreviations refer to the 646 location name (see Table S1 for details). The underlying ${ }^{137} \mathrm{Cs}$ soil data (decay corrected to 647 spring 2018) are derived from the Atlas of Radioactive Contamination of Ukraine (Intelligence 648 Systems GEO, 2011).

FIGURE 2 Composition of bacterial communities in wetlands within and outside Chernobyl. (a) Number of unique and shared amplicon sequence variants (ASVs) in each environment type, (b) alpha diversity, (c) richness, and (d) phylogenetic diversity.

FIGURE 3 Principal Coordinate Analysis (PCoA) on Bray-Curtis dissimilarity distances of the microbiomes in (a) all samples colored by environment type; and each environment type: (b) sediment, (c) soil, and (d) water.

FIGURE 4 Taxonomic composition of Chernobyl wetland microbiomes in sediment, soil, and water. Localities (x-axis) are arranged according to radiation levels with the right-most localities 661 having the highest radioactivity.

FIGURE 5 Differentially abundant taxa in Chernobyl wetland microbiomes in response to radiation levels in sediment, soil, and water. The error bars show the unstandardized effect size (beta) \pm standard error (SE). Y-axis lists significantly differentially abundant bacterial families (or the closest taxonomic order assigned). Positive log fold change indicates higher abundance in localities with higher radioactivity. 
bioRxiv preprint doi: https://doi.org/10.1101/2022.01.17.476627; this version posted January 20, 2022. The copyright holder for this preprint (which was not certified by peer review) is the author/funder, who has granted bioRxiv a license to display the preprint in perpetuity. It is made available under aCC-BY-NC-ND 4.0 International license.

TABLE 1 Permanova on the effects of radiation and environmental factors of the three environment microbiomes using Bray-Curtis distances. TDS $=$ Total Dissolved Solids, EC = Electrical Conductivity.

\begin{tabular}{|c|c|c|c|c|c|c|c|c|c|}
\hline & \multicolumn{3}{|c|}{ Sediment } & \multicolumn{3}{|c|}{ Soil } & \multicolumn{3}{|c|}{ Water } \\
\hline & $F$ & $R^{2}$ & $P$ & $F$ & $R^{2}$ & $P$ & $F$ & $R^{2}$ & $P$ \\
\hline Radiation & 1.420 & 0.068 & 0.035 & 1.567 & 0.075 & 0.013 & 1.466 & 0.063 & 0.066 \\
\hline Temperature & 1.049 & 0.050 & 0.377 & 1.599 & 0.077 & 0.016 & 1.910 & 0.082 & 0.008 \\
\hline $\mathrm{pH}$ & 1.245 & 0.060 & 0.133 & 0.950 & 0.046 & 0.562 & 1.603 & 0.069 & 0.055 \\
\hline TDS & 1.222 & 0.059 & 0.132 & 0.834 & 0.040 & 0.785 & 2.415 & 0.103 & 0.002 \\
\hline EC & 0.921 & 0.044 & 0.651 & 0.859 & 0.041 & 0.762 & 0.968 & 0.041 & 0.468 \\
\hline
\end{tabular}


bioRxiv preprint doi: https://doi.org/10.1101/2022.01.17.476627; this version posted January 20, 2022. The copyright holder for this preprint (which was not certified by peer review) is the author/funder, who has granted bioRxiv a license to display the preprint in perpetuity. It is made available under aCC-BY-NC-ND 4.0 International license.

\section{Figure 1}

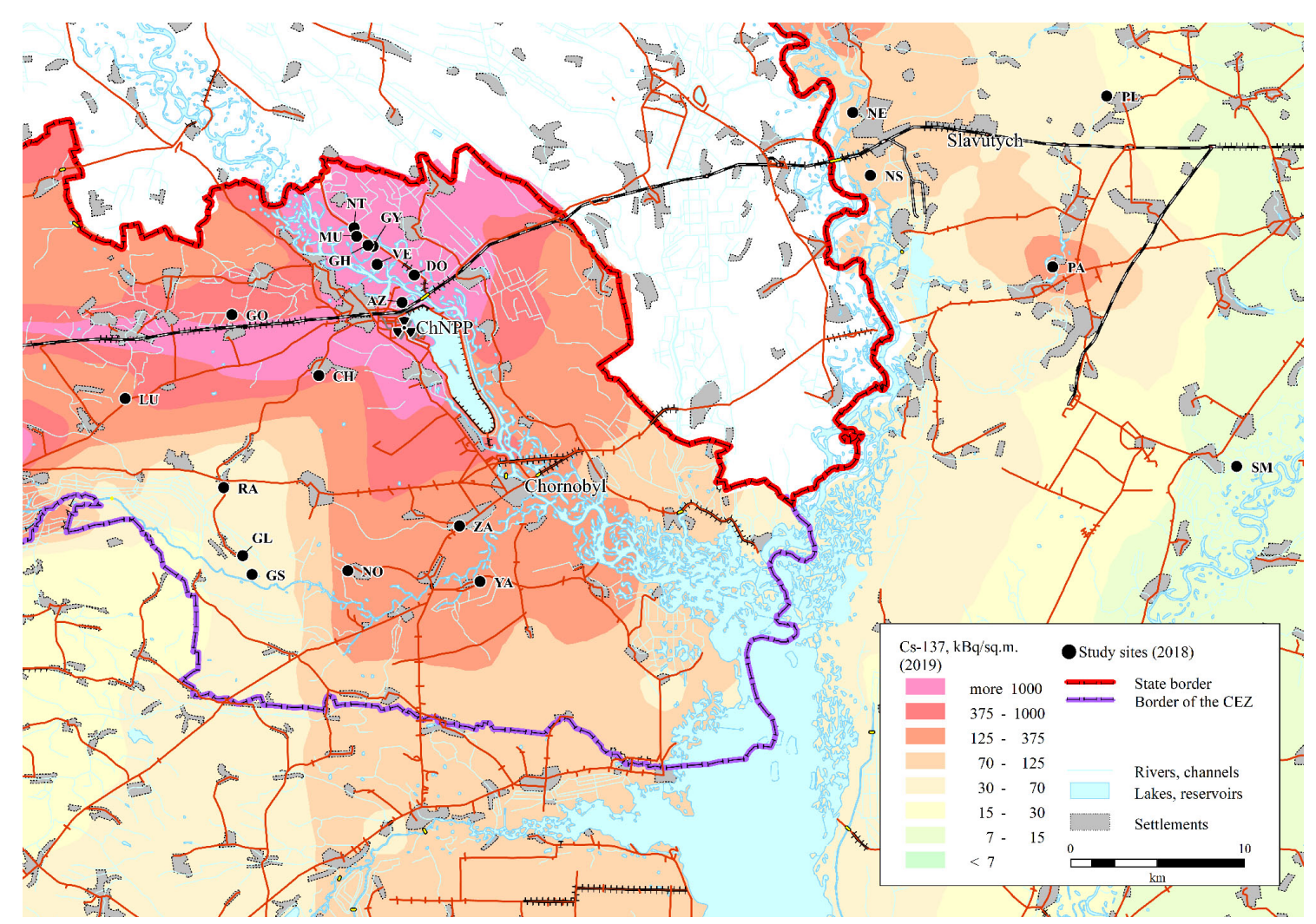


bioRxiv preprint doi: https://doi.org/10.1101/2022.01.17.476627; this version posted January $20,2022$. The copyright holder for this

preprint (which was not certified by peer review) is the author/funder, who has granted bioRxiv a license to display the preprint in perpetuity. It is made available under aCC-BY-NC-ND 4.0 International license.

\section{Figure 2}

(a)

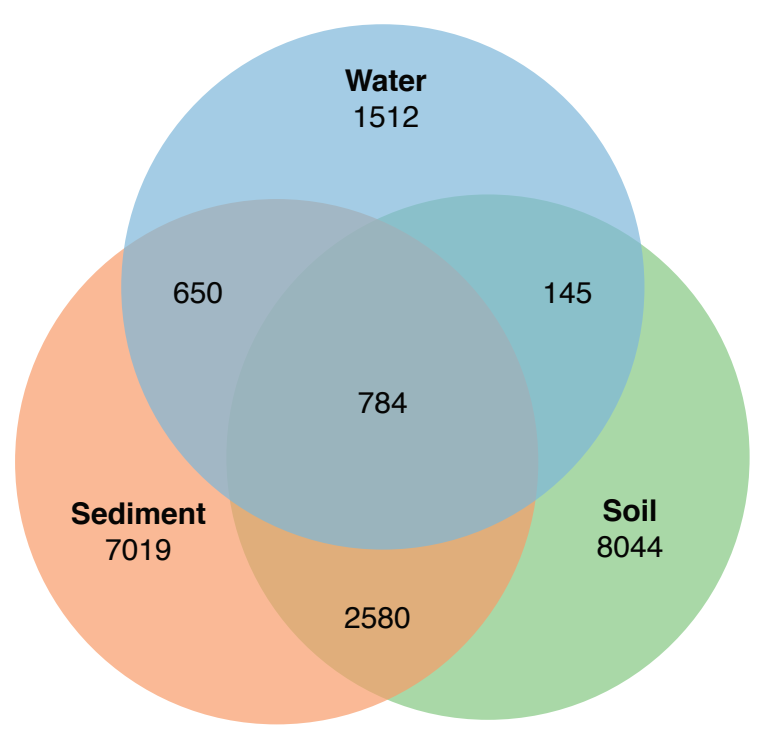

(c)

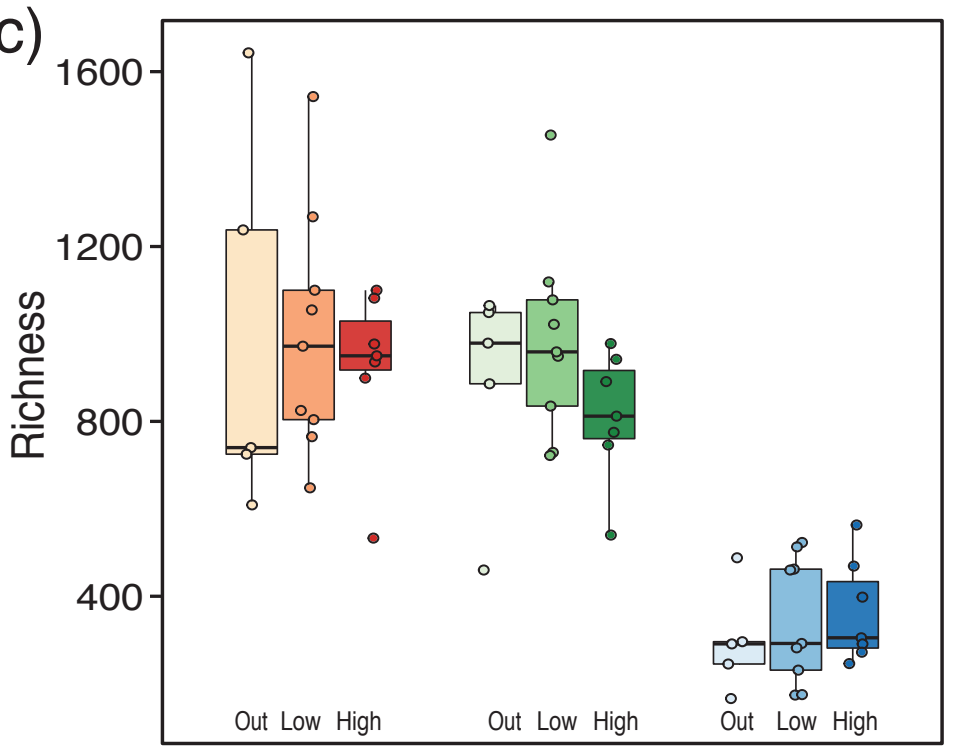

Sediment Soil Water (b)

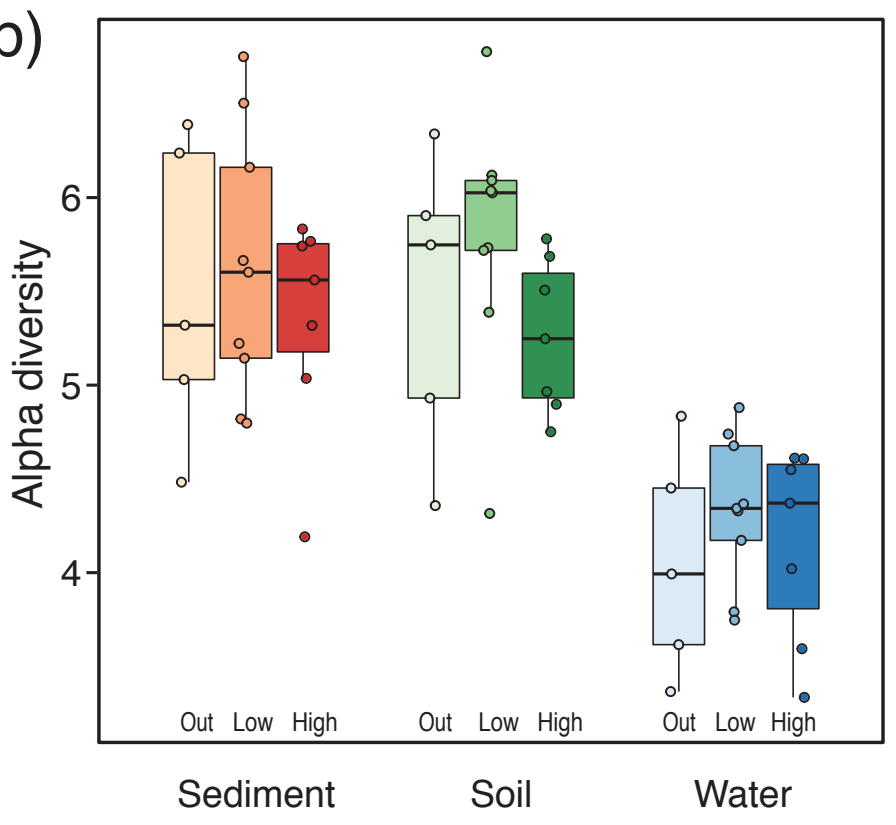

(d)

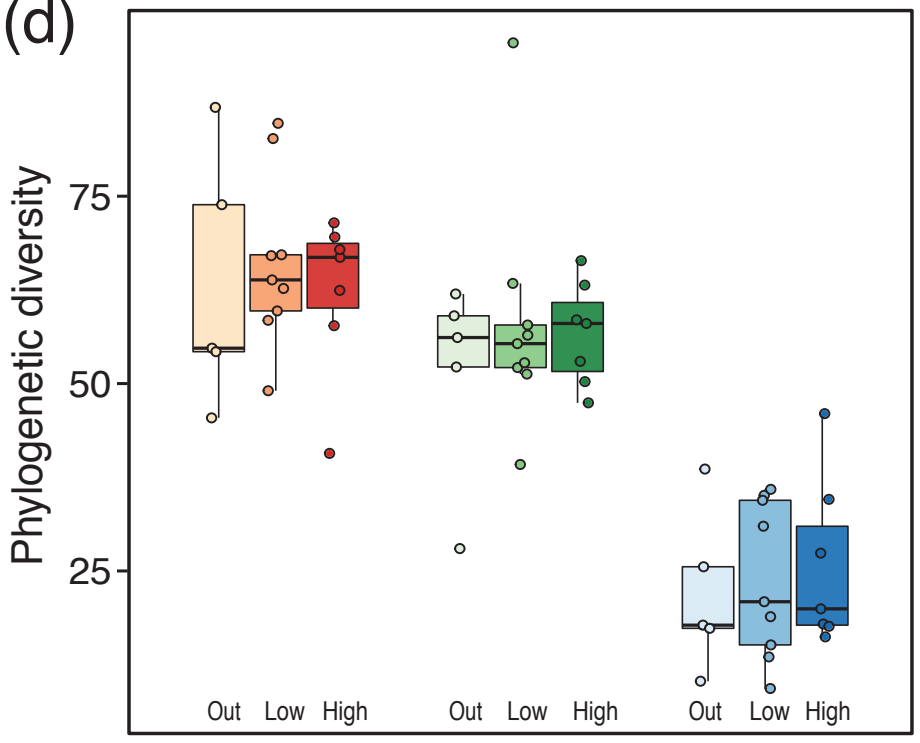

Sediment Soil
Water 


\section{Figure 3}

(a)

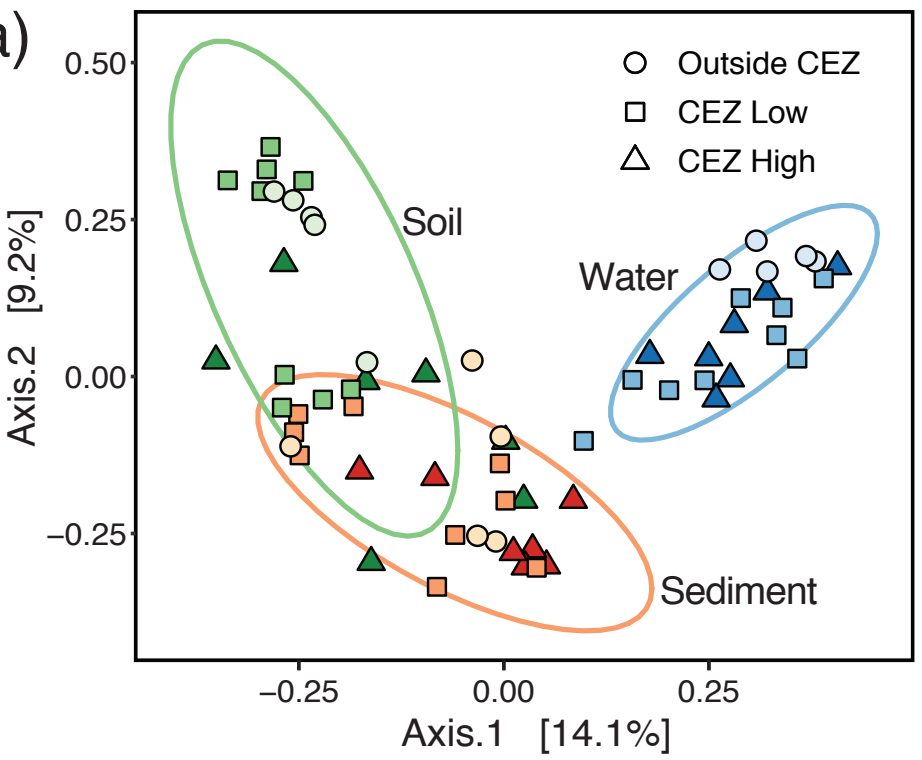

(c)

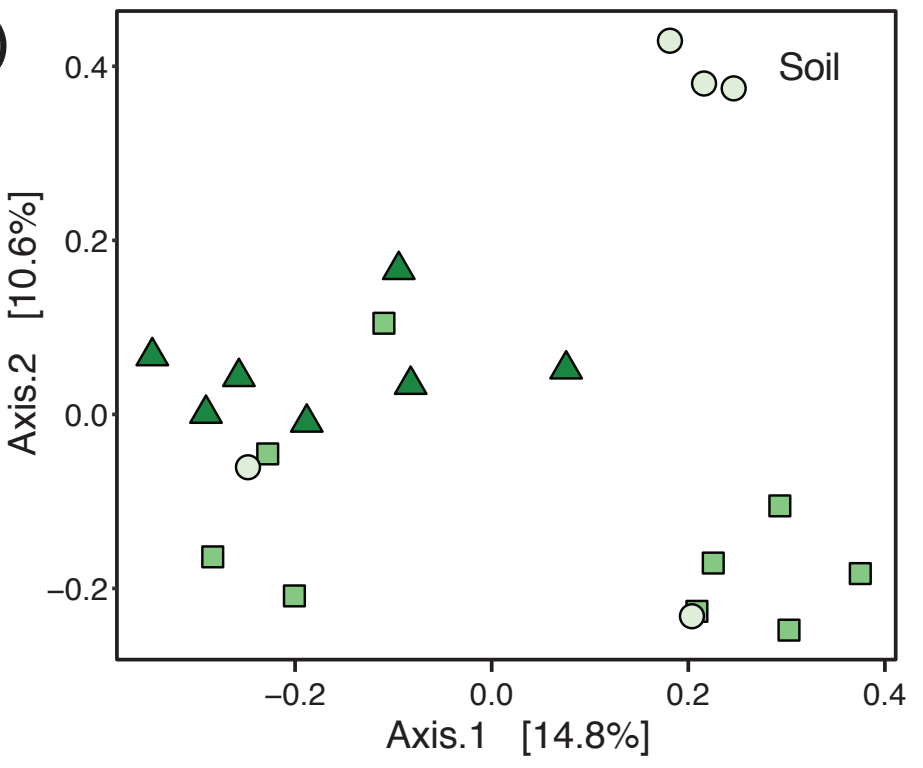

(b)

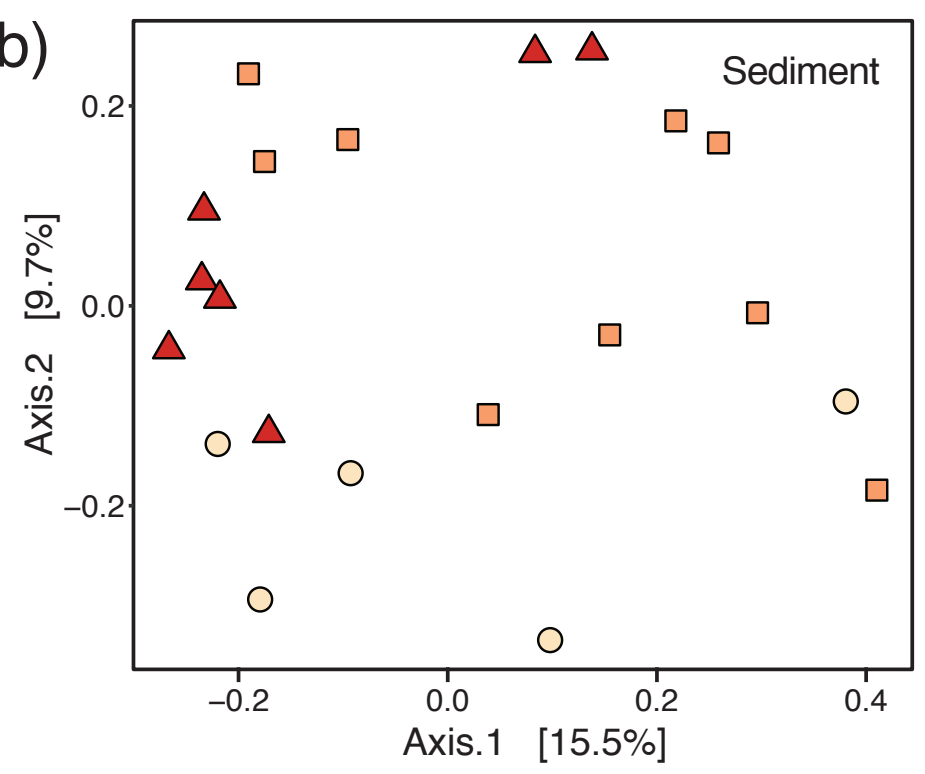

(d)

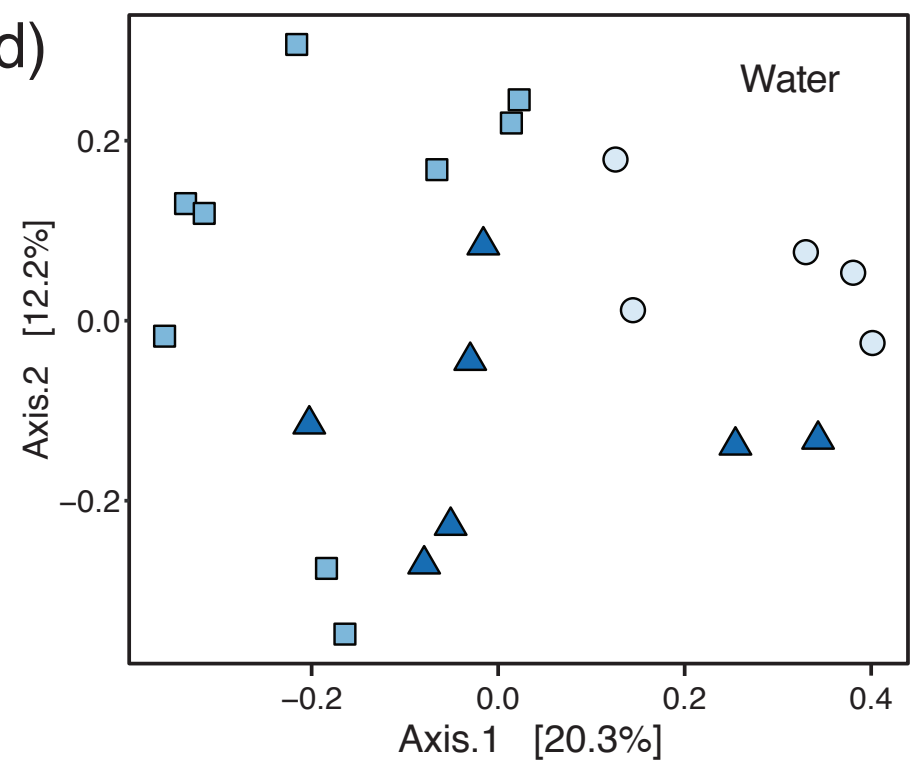


Figure 4
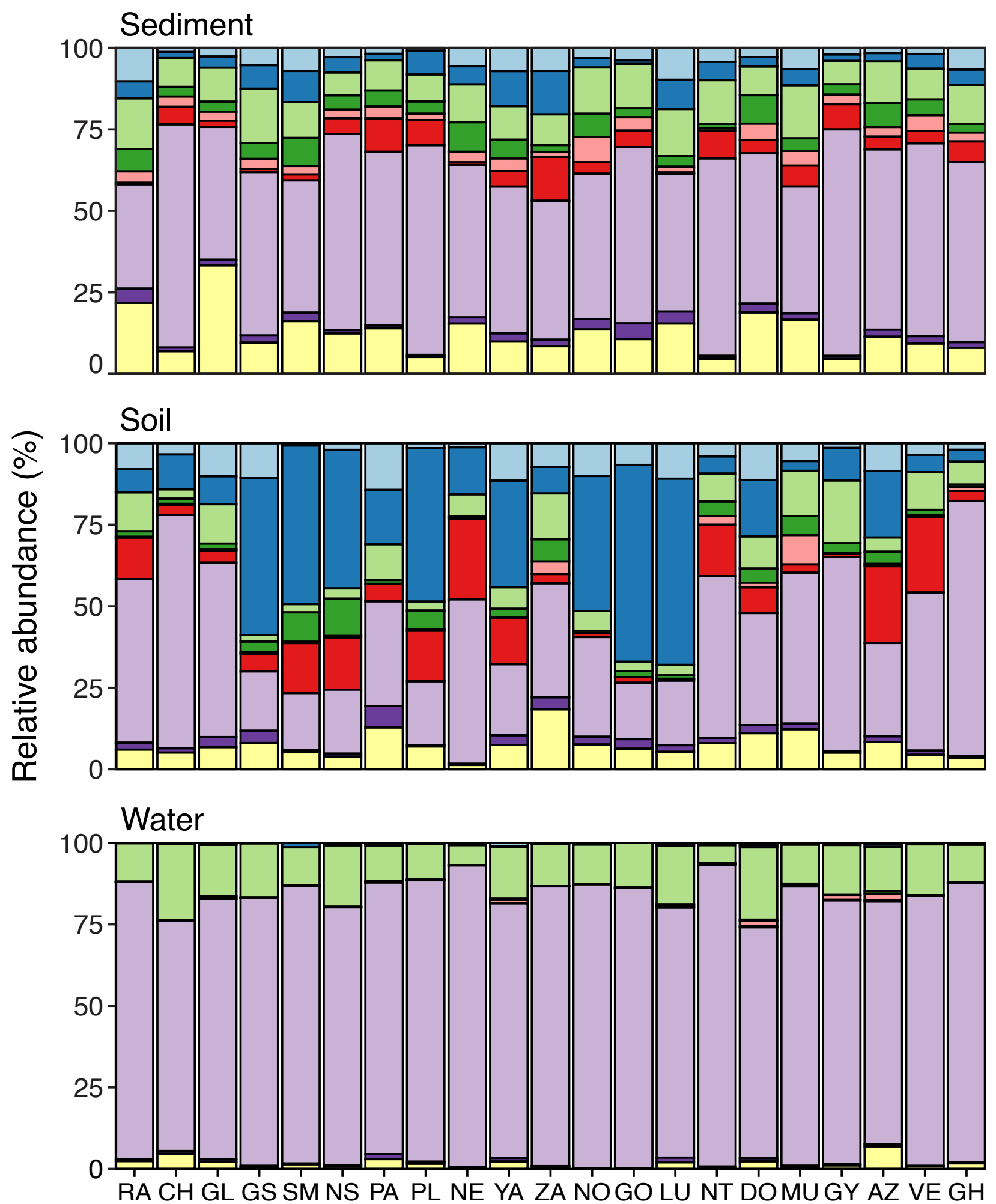

Phylum

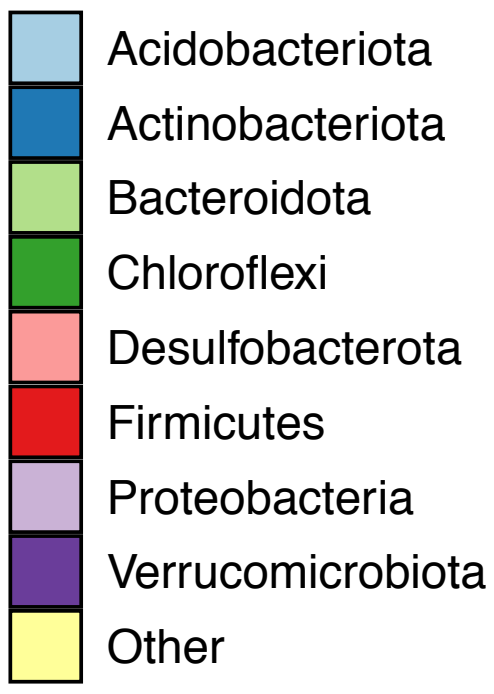

\section{Locality}


bioRxiv preprint doi: https://doi.org/10.1101/2022.01.17.476627; this version posted January $20,2022$. The copyright holder for this preprint (which was not certified by peer review) is the author/funder, who has granted bioRxiv a license to display the preprint in perpetuity. It is made available under aCC-BY-NC-ND 4.0 International license.

\section{Figure 5}

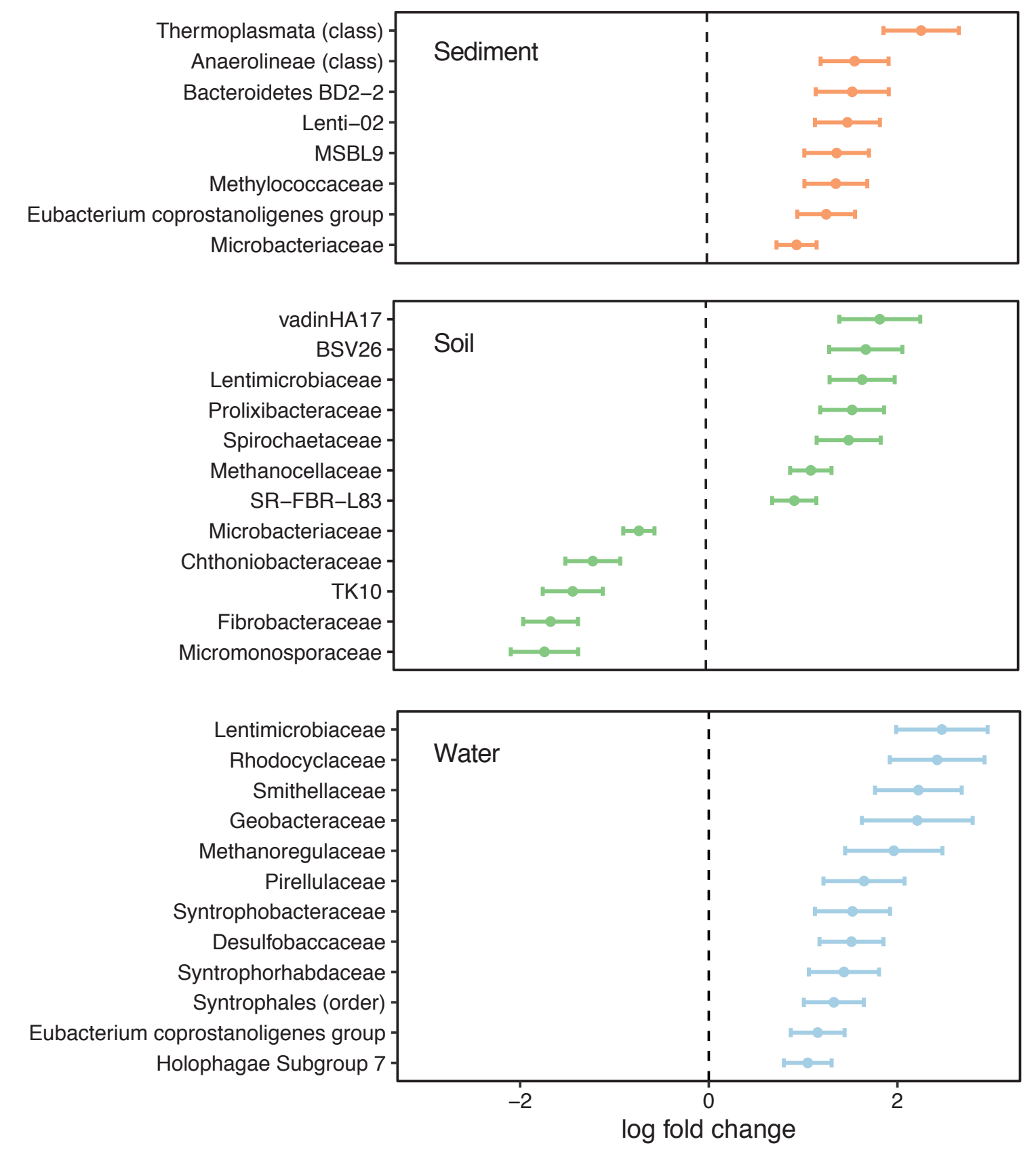


Table S1. Geographic coordinates (latitude and longitude), sampling date, current levels of radiation (in water, pond sediment and shore soil), and radiation area of the wetlands included in the study.

CEZ: Chernobyl Exclusion Zone.

Radiation $(\mu \mathrm{Sv} / \mathrm{h})$

\begin{tabular}{|c|c|c|c|c|c|c|c|}
\hline Locality & Code & GPS coordinates & $\begin{array}{l}\text { Sampling } \\
\text { date }\end{array}$ & Sediment & Soil & Water & $\begin{array}{r}\text { Radiation } \\
\text { area }\end{array}$ \\
\hline Glyboke Hydro & $\mathrm{GH}$ & $51.4453,30.0655$ & 29 May 2019 & 3.67 & 130.00 & 1.63 & CEZ High \\
\hline Vershina & VE & $51.4321,30.0756$ & 29 May 2019 & 3.54 & 21.60 & 2.76 & CEZ High \\
\hline Azbichin Lake & $A Z$ & $51.4056,30.1034$ & 30 May 2019 & 13.30 & 21.40 & 9.78 & CEZ High \\
\hline Glyboke & GY & $51.4447,30.0711$ & 29 May 2019 & 4.09 & 6.23 & 1.91 & CEZ High \\
\hline Muravka & MU & $51.4515,30.0528$ & 29 May 2019 & 2.45 & 4.47 & 0.84 & CEZ High \\
\hline Dolzhikovo & DO & $51.4247,30.1168$ & 29 May 2019 & 3.02 & 3.52 & 0.80 & CEZ High \\
\hline North Trace & NT & $51.4574,30.0499$ & 29 May 2019 & 2.10 & 2.92 & 1.20 & CEZ High \\
\hline Lubianka & LU & $51.3389,29.7956$ & 30 May 2019 & 0.17 & 0.33 & 0.20 & CEZ LoW \\
\hline Gorodische & GO & $51.3971,29.9141$ & 30 May 2019 & 0.07 & 0.19 & 0.06 & CEZ Low \\
\hline Novosiolki & NO & $51.2195,30.0430$ & 30 May 2019 & 0.13 & 0.18 & 0.10 & CEZ Low \\
\hline Zalesie & ZA & $51.2506,30.1669$ & 30 May 2019 & 0.14 & 0.17 & 0.08 & CEZ LoW \\
\hline Yampol & YA & $51.2119,30.1899$ & 30 May 2019 & 0.09 & 0.14 & 0.07 & CEZ Low \\
\hline Glinka SE & GS & $51.2168,29.9367$ & 30 May 2019 & 0.06 & 0.08 & 0.05 & CEZ LoW \\
\hline Glinka & GL & $51.2299,29.9263$ & 30 May 2019 & 0.08 & 0.08 & 0.06 & CEZ LoW \\
\hline Chistohalovka & $\mathrm{CH}$ & $51.3549,30.0108$ & 30 May 2019 & 0.11 & 0.08 & 0.09 & CEZ Low \\
\hline Razjezzheie & RA & $51.2771,29.9051$ & 30 May 2019 & 0.05 & 0.07 & 0.05 & CEZ LOW \\
\hline Nedanchichy NW & NE & $51.5375,30.6040$ & 3 June 2019 & 0.13 & 0.13 & 0.09 & Outside CEZ \\
\hline Nedanchichy SW & NS & $51.4938,30.6236$ & 2 June 2019 & 0.09 & 0.10 & 0.09 & Outside CEZ \\
\hline Plekhov & PL & $51.5489,30.8862$ & 2 June 2019 & 0.06 & 0.10 & 0.07 & Outside CEZ \\
\hline Pakulka & PA & $51.4304,30.8262$ & 1 June 2019 & 0.06 & 0.10 & 0.06 & Outside CEZ \\
\hline Smolin & SM & $51.2919,31.0304$ & 3 June 2019 & 0.06 & 0.09 & 0.04 & Outside CEZ \\
\hline
\end{tabular}


bioRxiv preprint doi: https://doi.org/10.1101/2022.01.17.476627; this version posted January 20, 2022. The copyright holder for this preprint (which was not certified by peer review) is the author/funder, who has granted bioRxiv a license to display the preprint in perpetuity. It is made available under aCC-BY-NC-ND 4.0 International license.

Figure S1

(a)

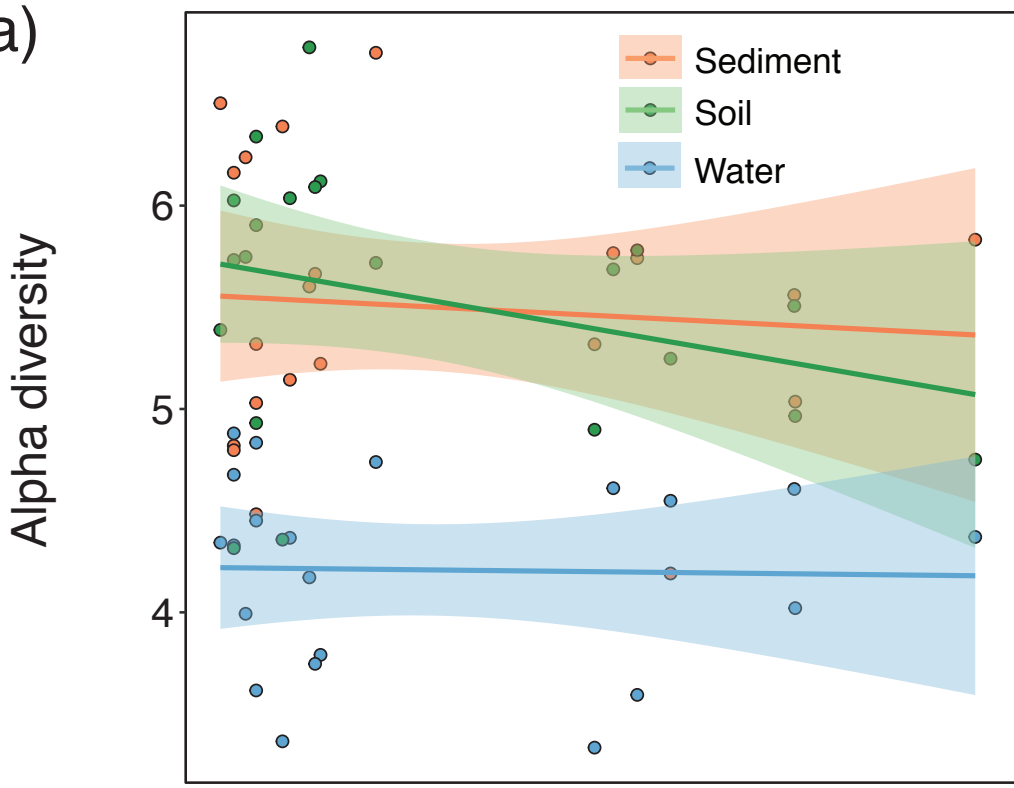

(b)

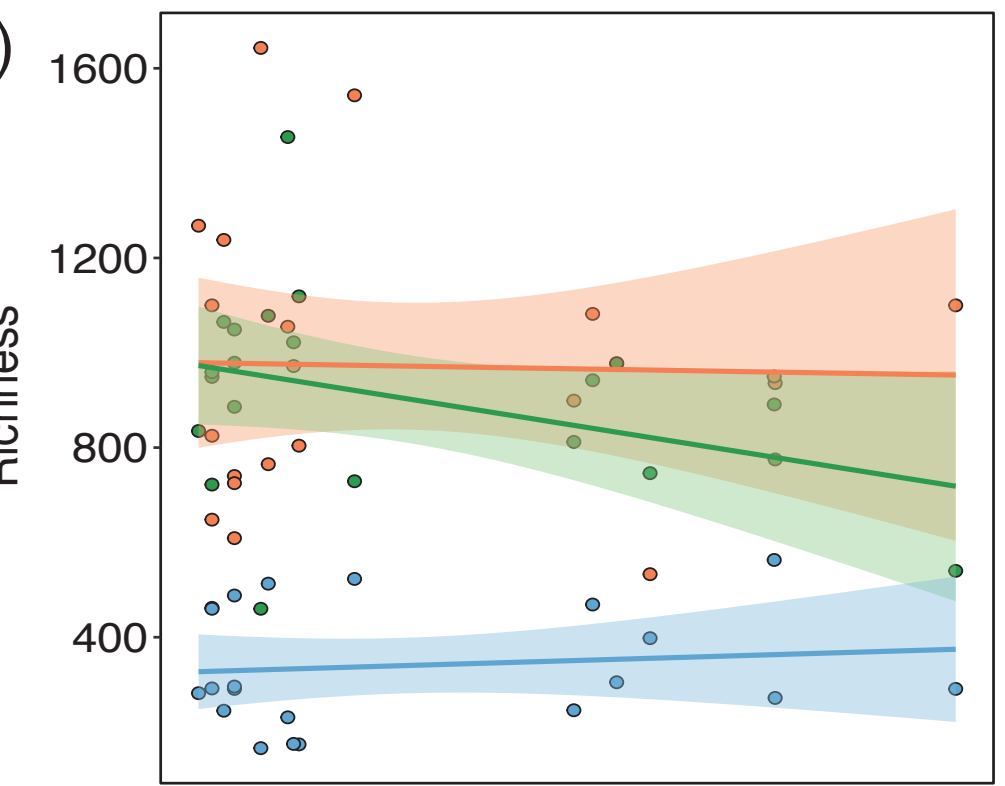

(c)

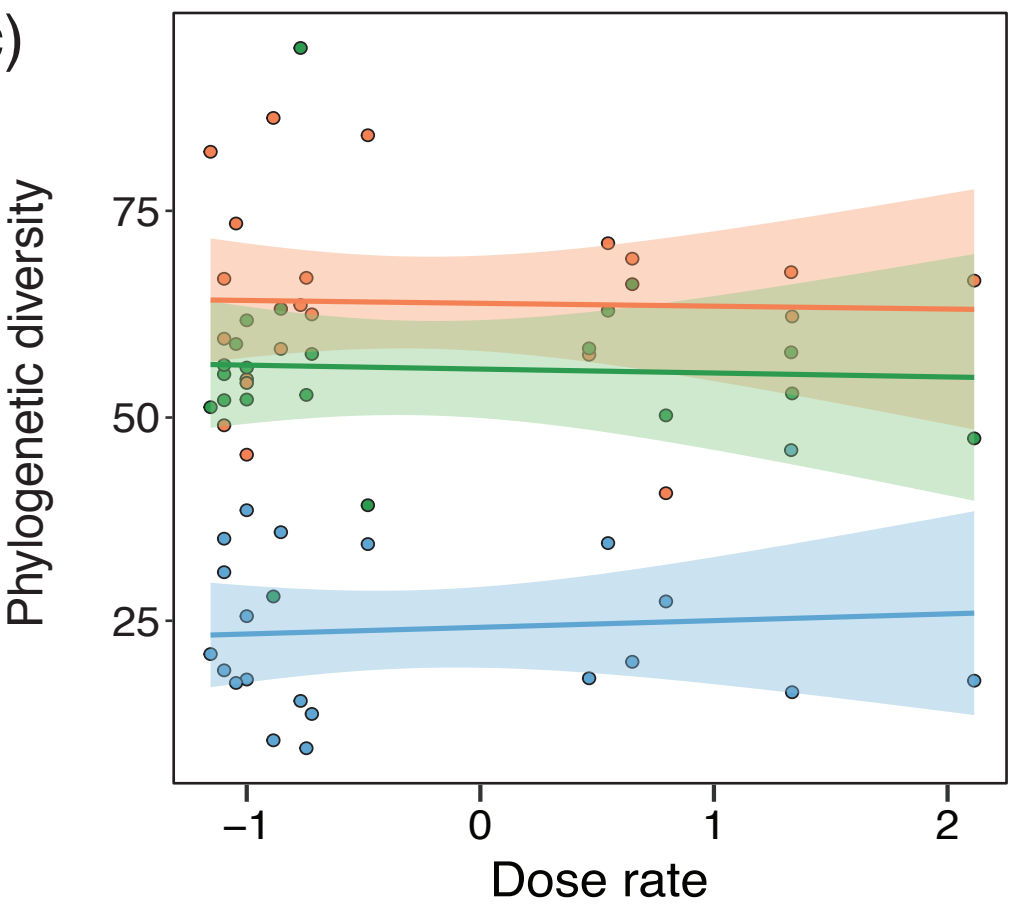

